\title{
NAGYCENKI TAMÁS
}

\section{A bünszervezetben történő elkövetés megállapíthatóságának ítélkezési gyakorlata a kábítószer-bünözés vonatkozásában $1{ }^{1}$}

\begin{abstract}
A kábítószerrel kapcsolatos tevékenységböl - így a termelésből, termesztésből, illetve a kereskedelemből - hatalmas jövedelemre tesznek szert a kábítószerhez köthető személyek, szervezetek. A kábítószer-bünözés és a szervezett bünözés veszélyessége nem kétséges, ez a veszély hatványozottan jelentkezik, ha a kábítószer-bünözés eléri a társas elkövetési alakzatok bünszervezeti formáját.

A bủnszervezetben történő elkövetés megállapítása egyebek között azért kardinális kérdés, mivel a törvény a bủnszervezetekhez rendkívül súlyos jogkövetkezményeket füz: kizárt a feltételes szabadságra bocsátás; a szabadságvesztés végrehajtási fokozata fegyház; a büntetési tétel felső határa a kétszeresére emelkedik; kötelező vagyonelkobzás a vagyonra, amelyet az elkövető bünszervezetben való részvétele ideje alatt szerzett.

Az értekezés célja egyrészt annak bemutatása, elemzése, hogy a bíróságok milyen bizonyítékok alapján állapítják meg az ítéletekben a bünszervezetben történő elkövetést; másrészt hogy mennyire egységes a szervezett kábítószer-bünözéssel kapcsolatos bírói gyakorlat.

Az említett cél megvalósításához elengedhetetlen volt a bírósági határozatok közül a szervezett kábítószer-bünözéssel kapcsolatos ítéletek, végzések kigyüjtése. A bűnszervezeti szintet elérő jogesetek száma a kábítószer-bűnözésen belül elenyészö, évente nagyjából egy-három, ez természetesen nem azt jelenti, hogy nem érdemelnek kiemelt figyelmet, hiszen egy-egy bünszervezet több száz, akár ezer fogyasztót láthat el kábítószerrel. A következőkben olyan bünszervezeteket is bemutatok, amelyek évi kétmillió eurós forgalommal, kokainnyeléssel, vagy száznyolcvanezer ecstasy tablettával hozhatók összefüggésbe.
\end{abstract}

1 A tanulmány következő részét júniusi számunkban adjuk közre. 


\section{Első ügy}

Az elsőrendü vádlott 2002-ben közölte a másod- és harmadrendű vádlottal, hogy könnyü pénzkereseti lehetőség adódott, fejenként, illetve alkalmanként kétszáz-háromszázezer forintot ajánlott azért, hogy kábítószert hozzanak Magyarországra Hollandiából. 2002 októbere és 2003 januárja között a másodés harmadrendű vádlottak legkevesebb négyszer csempésztek be kilenc kilogrammot meghaladó mennyiségü marihuánát az országba. A vádlottak a Hollandiában megszerzett kábítószert a gépjármüvük pótkerekébe rejtették, Magyarországon a marihuánát az elsőrendü vádlottnak adták át. ${ }^{2}$

A bíróság kiemelte a telefonkapcsolatok gyakoriságát, a vádlottak között ugyanis hetekig nem történtek telefonhívások, de amikor a másod- és a harmadrendủ vádlottak megszerezték Hollandiában a kábítószert, illetve Magyarországra hozták, kiemelkedően megnőtt a telefonhívások száma. A konspirációt bizonyítja, hogy a vádlottaknak legalább két mobiltelefonjuk volt.

A kábítószer mennyisége kapcsán a bíróság megállapította, hogy ennyi kábítószer értékesítésére egy ember egyedül nem képes.

A Somogy Megyei Bíróság szerint a „vádlottak a Hollandiából Magyarországra történö kábitószer-szállitást szervezetten, egymás tevékenységét elösegitve, azt kiegészitve bonyolitották le"’.

Mind az első-, mind a másodrendủ vádlott megemlítette, hogy a beszervezésükkor megfenyegették őket: ha az esetleges lebukás után beszélnek a hatóságoknak a kábítószer-kereskedelemről, nekik, illetve a családjaiknak bajuk eshet.

Az eljárás során a másodrendủ vádlott teljes körü feltáró vallomást tett, amelyet a bíróság elfogadott, mivel indokolása szerint a beismerő vallomást a rendelkezésre álló egyéb bizonyítékok is alátámasztották.

Az ítélet indokolásában kifejtettek szerint a bizonyítékok alapján a vádlottak terhére csak a kábítószer szállítása állapítható meg, az elosztásban való részvételük nem bizonyított. Ennek ellenére a vádlottaknak - a mennyiségre, illetve a rendszerességre tekintettel - tisztában kellett lenniük azzal, hogy a kábítószert ők juttatják el az elosztókhoz.

2 A Somogy Megyei Bíróság B.675/2004/114. számú itélete; a Pécsi Ítélótábla Bf.II.172/2007/26. számú ítélete; a Legfelsőbb Bíróság Bfv.III.342/2009/5. számú végzése.

3 A Somogy Megyei Bíróság B.675/2004/114. számú ítélete. 
A Somogy Megyei Bíróság a vádlottakat kereskedéssel jelentős mennyiségü kábítószerrel elkövetett kábítószerrel visszaélés büntettében mondta ki bünösnek.

Kiemelendő, hogy a bủnszervezet megállapíthatóságának kérdése az ítéletben szóba sem került.

A Pécsi Fellebbviteli Főügyészség a büncselekmények bünszervezetben elkövetettként minősítésére tett indítványt, ezért a másodfokú bíróság vizsgálta a bünszervezet megállapíthatóságát.

A Pécsi Ítélőtábla a Somogy Megyei Bíróság ítéletét megváltoztatta, és megállapította, hogy az első-, a másod- és a harmadrendủ vádlottak bünszervezetben részvétel miatt elítéltek.

Az ítélőtábla az indokolásban kitért arra, hogy a tényállásban meghatározott személyeken kívül többen közremüködtek a büncselekmények elkövetésében. Az eljárásban ismeretlenek voltak, akik a kábítószer hollandiai, illetve magyarországi forgalmazásában részt vettek, továbbá nem azonosították be azt a személyt sem, aki a rotterdami szállásról gondoskodott.

A bünszervezet fogalmi elemei vizsgálatakor az ítélőtábla megállapította, hogy a ,négy hónapon keresztül zajló, elkülönitetten hat részre bontható cselekménysorozat messze túlmutatott az alkalmi jellegü elkövetésen: nyilvánvalóan ennél hosszabb időre és tartós együttmüködés céljából szervezödött, olyan feladatmegosztással, amely már önmagában tervszerü, összehangolt müködést feltételezett. E tekintetben nem lehetett végül figyelmen kivül hagyni a tettenérések jelentöségét sem; azt a tényt, hogy a büncselekményeknek a nyomozó hatóságok közbeavatkozása, illetve a vádlottakkal szemben elrendelt elözetes fogvatartás vetett csak véget."

A Pécsi Î́télőtábla jogerős ítélete ellen az elsőrendű terhelt felülvizsgálati indítványt terjesztett elő. Az indítvány szerint a bünszervezetben elkövetés megállapítása is törvénysértő, mivel bünszervezetre utalás sem a vádiratban, sem az elsőfokú ítéletben nem található.

A Legfőbb Ügyészség álláspontja szerint mind a bủnszervezetben elkövetés, mind a feltételes szabadságból való kizárás törvényes volt.

A Legfelsőbb Bíróság megállapította, hogy „....kétségtelen, hogy a büncselekmény tervszerü, az egyes feladatok szerint összehangolt, többszöri megvalósítását a három terhelt közösen határozta el, szervezte meg, mig az ekkénti elkövetésben a terheltek mellett más személyek is részt vettek". ${ }^{\text {Az }}$

4 A Pécsi Ítélőtábla Bf.II.172/2007/26. számú ítélete.

5 A Legfelsőbb Bíróság Bfv.III.342/2009/5. számú végzése. 
előbbiek miatt törvényes volt a bủncselekmény bünszervezetben történő elkövetésének megállapítása.

Továbbá a Legfelsőbb Bíróság megjegyezte, hogy „,... a Pécsi Ítélőtábla helyesen fejtette ki, hogy az azonos törvényi tényállás alá eső elkövetési magatartások-az 1/2007. BJE I. pontja értelmében - természetes egységbe tartozása nem akadálya a bünszervezetben elkövetés megállapitásának. Jelen ügyben a tényállás egyes pontjai szerinti elkövetési magatartások önmagukban is 5 évet meghaladó szabadságvesztéssel büntetendök."

A Legfelsőbb Bíróság a Pécsi Ítélőtábla ítéletét az elsőrendű terhelt vonatkozásában hatályában fenntartotta.

\section{Második ügy}

A vádlott, aki bútorgyártással, -kereskedéssel foglalkozott, 1999-ben nagy mennyiségü hasisgyantához jutott; a szállítmányt az irányítása alatt lévő egyébként fiktív személy nevén szereplő - gazdasági társasága révén kívánta Kanadába juttatni. A vádlott szervezte meg a hasisgyantának a cége által megvásárolt és felújított bútorokban történő elrejtését. A kábítószer mennyiségét jelzi, hogy kétszáz csomagnyi hasist rejtettek el a bútorokban, a hasis összmennyisége ezerkétszáz kilogrammot tett ki. Kanadában a szállítmányt rendőri ellenőrzés alá vonták, a kanadai nyomozók a kábítószert lefoglalták, a fuvarozókat elfogták. A kanadai céget - amely a bútorokat rendelte - kizárólag azért alapították, hogy fedöcégként müködhessen. A második szállítmány (szekrények, komódok, dupla fenekü padok) tartalma ezernyolcszáz kilogramm hasisgyantát tett ki. A kanadai hatóságok ellenőrzött szállitást végeztek, azaz követték a bútorok útját; ennek segítségével nemcsak a fuvarozókat, hanem a bünszervezet terjesztő tagjait is letartóztatták.?

A kanadai hatóság által lefoglalt hasisgyanta a hatályos magyar Btk. szerint jelentős mennyiségü kábítószernek minősült, a jelentős mennyiség alsó határának tizenötezerszerese.

A Fővárosi Bíróság az ítéletében kifejtette, hogy a Btk. 137. § 8. pontja szerinti bünszervezet fogalma többször módosult. A Btk. legelső bünszerve-

7 A Fővárosi Bíróság 14.B. 913/2006/45. számú ítélete; a Fővárosi Ítélőtábla 3.Bf.63/2008/14. számú ítélete.
} 
zet-fogalma a következő volt: büncselekmények folyamatos elkövetésére létrejövö - olyan munkamegosztáson alapuló - bünszövetség, amelynek célja a rendszeres haszonszerzés.

Az 1998. évi LXXXVII. tv. 34. §-a a következőképp módosította a bünszervezet fogalmát: a büncselekmények rendszeres elkövetése révén haszonszerzés céljából létrejövö olyan bünszövetség, amely feladatmegosztáson, alá-fölé rendeltségi rendszeren és személyi kapcsolatokon nyugvó szerepvállaláson alapul.

A bíróság kifejtette, hogy a hatályos törvényszöveg - amelyet a 2001. évi CXXI. tv. 19. § (5) bekezdése állapított meg - szerint a bünszervezet: három vagy több személyböl álló, hosszabb időre szervezett, összehangoltan müködö csoport, amelynek célja ötévi vagy ezt meghaladó szabadságvesztéssel büntetendö szándékos büncselekmények elkövetése.

A büncselekmények bủnszervezetben való elkövetése a társas elkövetés speciális alakzata, a bíróság szerint a társadalomra veszélyesség kiemelten magas fokát mutatja.

A Fővárosi Bíróság rámutatott, hogy az ügyben a bünszervezet fogalmi elemei látszólag nem rajzolódnak ki, azaz a vádlott egyedüli elkövető volt, nincs összehangoltan müködő csoport.

A bíróság hivatkozott a Legfelsőbb Bíróság 4/2005. számú BJE határozatára, amely szerint a bünszervezetben elkövetés megállapítható azzal szemben is, aki eseti jelleggel akár egyetlen cselekményt tettesként vagy társtettesként valósít meg, ha az elkövető tudata a bünszervezet tárgyi ismérveit átfogja. A bíróság úgy ítélte meg, hogy a vádlott azon magatartásaival, amelyekkel két alkalommal juttatott hasisgyantát Kanadába, még nem vált a bünszervezet tagjává, azonban ,, a büncselekmény jellegéböl, a kábitószer mennyiségéböl tisztában volt azzal, hogy a kábitószernek ilyen mennyiségben a fogyasztókhoz történő eljuttatása különbözö személyek együttmüködését feltételezi és ez a csoport jól összehangoltan, rendszeres tevékenységet folytatva müködik"”.

A bíróság arra az álláspontra helyezkedett, hogy a vádlott a büncselekményt egy bűnszervezet müködéséhez kapcsolódva követte el úgy, hogy a végrehajtás körülményeiből a bűnszervezetben történő elkövetést felismerte.

Az említett ügyben a Fővárosi Bíróság az elsőrendủ vádlottat első fokon bünösnek mondta ki bünszervezet keretében jelentős mennyiségü kábítószerre kereskedéssel elkövetett kábítószerrel visszaélés bűntettében.

8 A Fővárosi Bíróság 14.B. 913/2006/45. számú ítélete. 
Az elsőfokú ítélet ellen az ügyészség a főbüntetés jelentős súlyosítása érdekében, a vádlott és védője pedig felmentésért fellebbezett.

A fellebbviteli ügyész álláspontja az volt, hogy az elsőfokú bíróság helyesen állapította meg, hogy a vádlott egy alá-fölé rendeltségi viszonyokkal jellemezhető nemzetközi bünszervezet keretei között tevékenykedett.

A Fővárosi Ítélőtábla a Fővárosi Bíróság ítéletét megváltoztatta: a vádlott föbüntetését tizenkét évről tízévi fegyházbüntetésre enyhítette, továbbá mellőzte a bünszervezetre utalást és a feltételes szabadságra bocsátást kizáró rendelkezést.

A másodfokú bíróság kitért a felderítés nehézségeire, mivel néhány lényeges bizonyíték kizárólag a külföldi terhelö tanú vallomása alapján a vallomásról készített videofelvétel révén állt az elsőfokú bíróság rendelkezésére. A másodfokú eljárás idejére az említett tanú elhunyt, egy másik külföldi tanú a hatóságokkal vádalkut kötött; további személyek a nyomozás során nem voltak felderíthetők.

A Fővárosi Bírósághoz hasonlóan a Fővárosi Ítélőtábla 1997-től levezette a bünszervezet fogalmának szabályozását, továbbá ismertette a 4/2005. számú BJE határozat lényeges elemeit.

A bíróság ezt követően kiemelte, hogy a Fővárosi Főügyészség a vádiratban nem jelölt meg olyan tényeket, amelyek a bünszervezetre utalnak; a vádiratban kizárólag annak elkövetéskori fogalma szerepelt; az ítélőtábla szerint a Fővárosi Bíróság ugyanezt rögzítette az ítéletben.

Az ítélet indokolásában nem szerepelt annak magyarázata, hogy az elsőfokú bíróság mi alapján jutott arra a következtetésre, hogy a vádlott tudata átfogta a bünszervezetet, továbbá milyen tárgyi ismérvek alapján állapította meg a bünszervezetben elkövetést.

A másodfokú bíróság kiemelte, hogy sem az ügyészség, sem az elsőfokú bíróság nem jelölt meg olyan bizonyítékokat, amelyek elengedhetetlenek a bünszervezet fogalmi elemeinek megállapításához; ennek az volt az oka, hogy a bizonyítási anyagban ilyen bizonyítékok nem voltak.

A Fővárosi Ítélőtábla megállapította, hogy az elsőfokú bíróság nem tett eleget a Legfelsőbb Bíróság 4/2005. számú BJE határozatában előírt követelményeknek; a bünszervezet fogalmát kizárólag a törvény alapján határozta meg, a vádlott - a bünszervezet tárgyi sajátosságaira vonatkozó - tudattartalmát nem vizsgálta meg, vagyis azt, hogy felismerte-e a bünszervezet tárgyi sajátosságait. Mindezen okok alapján a Fővárosi Ítélőtábla a bünszervezetben elkövetés megállapítását mellőzte. 


\section{Harmadik ügy}

A vádlottak különböző kábítószereket, marihuánát, ecstasy tablettákat szállítottak Magyarországra. Az elsőrendủ vádlott 2002. december 7. és 2003. március 29. között (a dátumoknak a későbbiekben fontos szerepük lesz) összesen öt alkalommal hozatott marihuánát az országba. Az elsőrendủ vádlott szervezte be a másodrendü vádlottat, akinek a kábítószer futárnak történő átadása, a szállítás biztosítása, szervezése volt a feladata. A másodrendű vádlott az elsőrendü vádlott által vett repülőjeggyel utazott külföldre, ott autót bérelt, és ismeretlen személytől vette át a kábítószert. A harmadrendủ vádlott a díler szerepét töltötte be, ő értékesítette az országba behozott kábítószert a fogyasztók, illetve viszonteladók részére, továbbá megbízást adott a nyolcad- és kilencedrendủ vádlottnak marihuána termesztésére. A negyedrendủ vádlott fogadta, tárolta és továbbította a másodrendű vádlott által a futár részére átadott kábítószert. Ö szervezte be az ötödrendủ vádlottat, aki kamionsoförként a futár feladatát látta el. Az ötödrendủ vádlottat a negyedrendủ vádlott látta el instrukciókkal, azonban a tevékenységét a másodrendủ vádlott is ellenőrizte. A hatodrendủ vádlott megbízta a hetedrendủ vádlottat, hogy vásároljon külföldön ecstasy tablettákat, és csempéssze Magyarországra. Miután a rendőrség elfogta az elsőrendủ vádlottat és társait, a harmadrendủ vádlott felvette a kapcsolatot hatodrendủ vádlottal, hogy biztosítson neki kábítószert; ezt követően a vádlott a hetedrendủ vádlottat bízta meg a kábítószer beszerzésével, behozatalával. A hetedrendű vádlott több mint kilenc és fél kilogramm marihuánát hozott az országba. A rendőri intézkedés után a hetedrendủ vádlott lakásából elökerült 6025 ecstasy tabletta is. ${ }^{9}$

A Fővárosi Főügyészség a vádiratában öt vádlott esetében tartotta indokoltnak a bünszervezetben történő elkövetés megállapítását.

A vádlottak együttmüködését bizonyítja a rengeteg telefonhívás, amelyek során általában virágnyelvet használtak. A telefonbeszélgetéseket a minimalizálás, illetve a „kódok” használata jellemezte; a szervezet tagjain kívül a laikusok alig érthetik meg a beszélgetések tartalmát. Az előbbiekre jó példa az ítéletben szereplö szöveg: ,Egy-két órán belül visszaszólok és összerakom a sajtot legalább. Küldd el, hogy mekkora amit odaadtál! Összesen volt kétszer tizenegy fél, kettö, három meg ötötven, kettö nyolcötven ha jól számolom.

9 A Fővárosi Bíróság 7.B.474/2004/253. számú ítélete; a Fővárosi Ítélőtábla 3.Bf.34/2009/16. számú ítélete; a Fővárosi Bíróság 7.B.983/2009/30. számú ítélete; a Fővárosi Ítélőtábla 3.Bf.127/2010/6. számú végzése; a Kúria Bfv.II.125/2012/9. számú végzése. 
Kétszer tizenegy. Hát a két egész. Az kettö, három. Meg ötötven, igen. Igen, akkor kettönyolcötven. Csak hogy tudjam, hogy mennyinél tartunk, meg hogy hogy állunk. [...] Van neked játékod? Játék? Hát van valamennyi. Olyan tízhúsz kéne. Jó majd megdumáljuk. "Io

A bíróság szerint egyértelmü volt a nyolc terhelt együttmüködése, aminek során mindegyikük személyre szabott feladatot látott el.

A bünszervezet fennállása kapcsán a bíróság arra a megállapításra jutott, hogy annak fogalmi elemei nem valósultak meg maradéktalanul. Az elsőfokú bíróság szerint az előbbiekben kiemelt két időpont között eltelt három hónap nem elegendő a bünszervezet megállapítására. A bíróság kimondta, hogy a vádlottak szervezetten müködtek együtt - ezt bizonyítják a telefonlehallgatások, híváslisták, a megfigyelések anyagai, a beismerö vallomások -, azonban a bíróság szerint nem volt elegendő adat a magasabb szervezettséget igénylö bünszervezet megállapításához.

Az ítéletben a bíróság kifejtette, nem lehetett egyértelmúen bizonyítani, hogy a vádlottak mindegyikének tudomása volt a szervezet müködéséről; kizárólag töredékes kapcsolatokat lehetett feltárni.

A bíróság a kilenc vádlott vonatkozásában folytatott büntetőügyben az elöbbiekben ismertetett tények miatt a bünszervezetben történő elkövetést nem állapította meg; a vádlottakat kábítószerrel visszaélés büntettében mondta ki bünösnek.

Az elsőfokú itélet ellen az ügyész súlyosításért; a vádlottak, illetve a védők felmentésért, illetve enyhítésért fellebbeztek.

A másodfokú bíróság megállapította, hogy az első-, másod-, harmad-, negyed-, hatod- és hetedrendủ vádlottak a terhükre rótt büncselekményeket bünszervezetben követték el.

A Fővárosi Ítélőtábla kifejtette, hogy a Fővárosi Bíróság a felvetődő bizonyítékok igen gondos és körültekintető értékelésével állapította meg a történeti tényállást.

Az ítélőtábla arra az álláspontra helyezkedett, hogy az elsőfokú bíróság által a tényállásban megállapított elkövetési idő - 2002. december 7. és 2003. március 29. között, illetve a hatod- és hetedrendủ vádlottak vonatkozásában a 2003. április 9. és 2003. május 29. között - elegendő a hosszabb idöre szervezettség megállapításához. A bíróság kiemelte, hogy ,, az újabb bünelkövetést a nyomozó hatóságok intézkedései akadályozták meg, nem a vádlottak döntöttek úgy, hogy ezzel felhagynak"'I.

10 A Fővárosi Bíróság 7.B.474/2004/253. számú ítélete.

11 A Fővárosi Ítélőtábla 3.Bf.34/2009/16. számú ítélete. 
A bünszervezet minimális létszámával kapcsolatban az egyik tényállásnál a bíróság álláspontja az volt, hogy többek között a fel nem derített személy, a holland elkövető figyelembevételével meghaladta a minimális létszámot a bünözői kör. Az összehangolt müködés nem volt kétséges, az ítélőtábla utalt a lehallgatási anyagokra.

Az ítélőtábla hivatkozott a 4/2005. számú BJE határozatra, idézte azokat a sorait, amelyek szerint „a bünszervezetben elkövetés megállapitható azzal szemben is, aki-eseti jelleggel - akár egyetlen cselekményt tettesként vagy részesként valósit meg, ha az elkövetö tudata a bünszervezet meghatározott tárgyi ismérveit átfogja". A másodfokú bíróság továbbá hivatkozott a $\mathrm{BH}$ 2007/3. számú eseti döntésre, amelyben megállapították a bünszervezet fennállását, amikor a vádlottak külön-külön hoztak be kábítószert Magyarországra, azonban a tudatuk átfogta azt, hogy a cselekményeiket legalább három személyt tartalmazó szervezet keretein belül követik el.

A Fővárosi Ítélőtábla megállapította, hogy az ítéleti tényállás tartalmazza az előbbiekben kifejtett eseti döntésben, illetve a jogegységi határozatban megkívánt fogalmi elemeket, ezért a bíróság kimondta a bünszervezetben történő elkövetést.

Az ötödrendű vádlott esetében az ítélőtábla hatályon kívül helyezte az elsőfokú ítéletet abszolút hatályon kívül helyezési ok miatt (két tárgyalási határnapon kamarából kizárt ügyvéd járt el a vádlott védelmében, holott a védelem kötelező volt), és új eljárásra utasította a Fővárosi Bíróságot.

A megismételt eljárásban a vádlott szerepe kapcsán a bíróság hangsúlyozta, hogy a bünszervezet létezéséröl tudomása volt, annak müködésében tevékenyen részt vett. Az eljárás során a vádlott , ....korábbi büntársait, valamint önmagát is következetesen terhelte, de nemcsak a büncselekmény elkövetésével, hanem azzal is, hogy mindezt szervezett formában hajtották végre. Állitásait a személyektöl független objektív bizonyitékok is mindenben alátámasztották. ",12

A kábítószert a vádlott kamionsoförként szállította Magyarországra, ,,...az egyes szállitások alkalmával pontosan kidolgozott terv szerint, meghatározott helyen és időben, mindig azonos személytöl vette át az árut és a biztonságos szállitást is felügyelték társai, akik útközben mindvégig mobiltelefonon tartották vele a kapcsolatot. A szállitmányok is mindig ugyanarra az elöre megszervezett biztonságos helyre érkeztek, ahol a címzett már várta az árut és gondoskodott annak biztonságos helyre történö tovább szállitásáról." ${ }_{13}$

12 A Fővárosi Bíróság 7.B.983/2009/30. számú ítélete. 13 Uo. 
A Fővárosi Bíróság az alapügy ötödrendủ vádlottját bünösnek mondta ki kábítószerrel visszaélés büntettében, és mint bünszervezetben elkövetőt fegyházbüntetésre ítélte.

A megismételt eljárásban a Fővárosi Bíróság által hozott ítélet ellen mind az ügyész, mind a vádlott és védője fellebbezett; a jogorvoslatok nem vezettek eredményre, a Fővárosi Ítélőtábla az elsőfokú bíróság ítéletét helybenhagyta.

A vádlott védője felülvizsgálati indítványt nyújtott be, a Kúria az elsőfokú bíróság ítéletét, illetve a másodfokú bíróság végzését hatályában fenntartotta.

A védő azzal érvelt, hogy a terhelt vonatkozásában anyagi jogszabálysértésnek minősül a bünszervezetben elkövetés megállapítása. Indoklásként kiemelte, hogy a terhelt cselekményei a 2002 decembere és 2003 márciusa közötti időszakra estek, a bünszervezetben történő elkövetést felvető ítélet 2009. júniusi. A védő vitatta a hosszabb időre történő elkövetést, ugyanis szerinte a három-négy hónapos időszak nem elegendő ennek megállapítására. Az összehangoltság szintén vitatható a védő szerint, ugyanis a terhelt csak egy terhelttársával állt személyes kapcsolatban.

A Kúria tanácsa kifejtette, hogy az eljáró bíróságok helyesen következtettek a büncselekmények bünszervezetben való elkövetésének megállapíthatóságára. Az elkövetési intervallum - a védő érvelésével ellentétben - elegendő a bünszervezetben elkövetés megállapításához, továbbá ,, a bünszervezetben elkövetés megállapitása szempontjából nem a terhelti tevékenység kifejtésének intervalluma a meghatározó (hiszen az akár egyetlen cselekmény tettesi vagy részesi megvalósitása esetén is megállapitható), hanem a teljes bün-

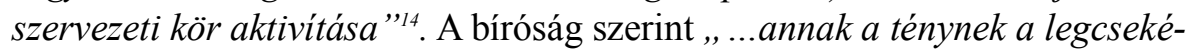
lyebb jelentösége sincs, hogy a terhelt a bünszervezet több, vagy valamennyi tagját nem ismeri, a szervezett elkövetés, minimálisan három személy egy irányba ható tevékenysége szükségességének a felismerése a követelmény. Márpedig az elkövetés körülményeiböl, a kábitószer átadásának és átvételének megszervezéséböl, de már önmagában a kábitószer mennyiségéböl is minderre egyértelmü következtetés vonható - miként az a terhelt eljárás során tett nyilatkozataiból is kitünik."

A Kúria az előbbiek miatt nem fogadta el a védő álláspontját, anyagi jogszabálysértést nem állapított meg.

14 A Kúria Bfv.II.125/2012/9. számú végzése. 15 Uo. 


\section{Negyedik ügy}

A huszadrendủ vádlott egy holland kábítószer-elő́llító, -forgalmazó bủnszervezet tagja volt, a bünszervezetben eleinte testőri, majd futári feladatokat látott el. Egy futárútja miatt Svédországban börtönbüntetésre ítélték, ennek ellenére hallgatott a társairól, a szervezet a hallgatást nyaralással, házzal, illetve pénzzel jutalmazta. A szabadulás után a vádlott a futárokat fogadta, intézkedett a szállásolásukról, a gépkocsik pótkerékbe rejtett kábítószer átadásáról, illetve végezte a kábítószerrel való elszámolást. A bünszervezet vezetői utasították a vádlottat, hogy hozzon létre olyan csoportokat, amelyek alkalmasak nagy mennyiségü kábítószer Magyarországra csempészésére. A vádlott állapodott meg a csoportok vezetőivel a kábítószerek fajtájáról, mennyiségéről, áráról; a vezetők a kábítószer értékével vele számoltak el, továbbá ő fogadta a reklamációkat. A huszadrendủ vádlott összesen négy magyar csoportot látott el kábítószerrel, az első csoportba hét, a másodikba hat, a harmadikba kettő, a negyedikbe négy elkövető tartozott. A négy egységet, csoportot tartalmazó bünszervezetben hat személy látott el irányítói feladatokat. A csempészésben tíz, míg a tárolásban, hígításban, átcsomagolásban, értékesítésben tizenegy személy vett részt. A kábítószer Magyarországon történő értékesítéséből keletkezett bevételt a csoportok vezetői gyüjtötték össze és számoltak el a huszadrendủ vádlottal; az elszámolások személyesen, átutalással, illetve futárral történtek. A harmad- és a negyedrendủ vádlott hat alkalommal összesen legalább száznyolcvanezer ecstasy tablettát, tizennyolc kilogramm amfetaminport és egy kilogramm kokaint csempészett az országba. Az említett kábítószer a jelentős mennyiség alsó határának kétszázháromszorosa volt. ${ }^{16}$

A bizonyítás szempontjából kiemelt figyelmet érdemeltek a lehallgatási anyagok, híváslisták, a híváslista-elemzésekről és értékeléséről, a cellapozíciókról készült jelentések, illetve a hírközlési szakértői vélemény.

A bíróság rámutatott, hogy a pert milyen széles körü nyomozás előzte meg, az ügy hat nyomozás egyesítésével jött létre; négy ügy nyomozását a Nemzeti Nyomozó Iroda szervezett bünözés elleni föosztály kábítószer-bünözés elleni osztálya végezte.

A huszadrendủ vádlott feltáró vallomást tett a holland bünszervezet müködéséröl, azt azonban tagadta, hogy bünszervezetet müködtetett volna. Val-

16 A Fővárosi Bíróság 8.B. 402/2007/245. számú itélete; a Fővárosi Ítélőtábla 3.Bf.146/2009/45. számú ítélete; a Legfelsőbb Bíróság Bhar.III.616/2010/24. számú ítélete. 
lomásában kifejtette, hogy a magyar futárok semmit sem jelentettek a szervezetnek, azaz a kisebb emberek „beáldozhatók” a nagyobbakért. A holland bünszervezethez olyan hírek jutottak el, hogy a magyar bünüldöző hatóságok nem tudtak nagyobb mennyiségủ kábítószert lefoglalni, ezért felvetődött a vezetők cseréje. A holland bünszervezet vezetői eldöntötték, hogy a kábítószer-csempészés fenntartása érdekében néhány magyar futárt megbuktatnak. A huszadrendủ vádlott szerint a büntetőügy vádlottjainak a holland szervezet szempontjából nem volt értékük. A vádlott arra is kitért, hogy a drogfutárok beszervezése az úgynevezett felderítők feladata volt.

A huszadrendü vádlott megjegyezte, hogy „,..én mikor megkaptam kintröl az utasitást, hogy minél több embert szervezzek be, és hogy a 2005-ös évet arra tesszük fel, hogy egy csomó embert bebuktatunk minél nagyobb mennyiséggel, onnantól mindegy volt, hogy kik lesznek ezek" ${ }^{\prime 7}$.

Bizonyítás tárgyául szolgált, hogy a vádlottak bünszervezetben valósították-e meg a terhükre rótt büncselekményeket.

A bíróság megállapította, hogy a vádlottak között létezett munkamegosztás, ,, az egyes tevékenységi formák azonban mereven nem különültek el egymástól, egy-egy vádlott a szervezeten belül több feladatot is ellátott"'ıs.

A vádlottak, illetve a védők vitatták a bünszervezet létét, arra hivatkoztak például, hogy a tagoknak nem szakaszosan kell megállapodniuk, hanem egyszerre.

A bíróság a bünszervezet vonatkozásában az ügyészi indítványt fogadta el; kifejtette, hogy a bünszervezet egy jogi terminus technicus meghatározott ismérvekkel, azonban ezeket a bírói gyakorlat folyton finomítja. A bünszervezet tárgyi ismérvei a hosszabb időtartam, a szervezettség, illetve az összehangoltság; az összehangoltságnak a szervezet oldalán kell fennállnia.

A Fővárosi Bíróság az ítéletében felhívta a 4/2005. számú BJE határozat több részletét; megállapította, hogy a bünszervezet törvényben megkívánt fogalmi elemei kétséget kizáróan megállapíthatók. A szervezet működését a hatóságok fellépése szakította meg, a szervezettséget bizonyítják a telefonlehallgatási anyagok, illetve az értékelhető vallomások.

$\mathrm{Az}$ itélet szerint ,önmagában az a tény, hogy Hollandiából, adott személytöl, folyamatosan nagy mennyiségü kábitószer jut Magyarországra ugyanazon módszer alkalmazásával, ezt önmagában egy haszonszerzésre törekvö, szervezetten tevékenykedö csoport képes megoldani. Ezzel a folyamat- 
tal valamennyi érintett vádlott tisztában volt, miután pedig e tevékenységen belül részfeladatokat vállaltak, illetve láttak el, vagyis külföldröl származó, jelentös mennyiségü kábitószer megrendelésével, Magyarországra csempészésével, tárolásával, csomagolásával, elosztásával, értékesitésével foglalkoztak, tevékenységük egymást kiegészitö, segitö volt, és ennek ismeretében, tudatában voltak, cselekményük bünszervezetben való elkövetés." 19

A húsz vádlott ellen folytatott büntetőeljárásban a bíróság tizenhét vádlott vonatkozásában állapította meg a bünszervezetben elkövetést, a huszadrendü vádlottat - halmazati büntetésül - tizennégy év fegyházbüntetésre ítélte.

Az elsőfokú bíróság ítélete ellen az ügyész; tíz vádlott, illetve valamenynyiük védője fellebbezett. A Fővárosi Ítélőtábla tizenhét vádlott esetében megváltoztatta az elsőfokú ítéletet. A harmadrendủ vádlott védőjének álláspontja szerint a bünszervezetet nem a huszadrendủ vádlott és társai, hanem nagy valószínüséggel magyar rendőrök megrendelésére hozták létre. A védői érvelés szerint a cél az volt, hogy nagy mennyiségü kábítószerrel lepleződjenek le bünszervezet látszatát keltve; továbbá kiemelte, hogy nem vonható le következtetés a vádlottak összehangolt, hosszú távú, haszonszerzésre törekvő együttmüködésére. Az összes vádlott védője vitatta a bünszervezetben elkövetés megállapíthatóságát.

A másodfokú bíróság kiemelte a huszadendủ vádlott beismerő vallomását: a saját magára, illetve a vádlott-társakra terhelő vallomáson kívül felfedte a bủnszervezeti hátteret.

A bíróság szerint három vádlott esetében kétséget kizáró módon nem volt megállapítható, hogy a kábítószer csempészésekor, illetve fogadásakor a vádlottak tudata átfogta volna a bünszervezet tényállási ismérveit.

A bíróság utalt rá, hogy a vádlottak a bünszervezeti hierarchia alján helyezkedtek el. A Fővárosi Itélótábla hangsúlyozta, hogy ,,mind a büntetőeljárásnak, mind a büntetés kiszabásnak az általános és egyéni megelözés mellett azt a célt kell jelen büncselekményeknél szolgálnia, hogy a kábítószer ne jusson el a fogyasztókhoz. A le nem foglalt kábítószerrel kapcsolatban a függöség kedvezöbb szabályai által motivált vádlotti beismerö vallomások teljes körü befogadása nem csupán egy nem bizonyított tény miatti büncselekmény megállapitását, hanem a nyomozásoknak nem a tényleges lefoglalás, hanem a virtuális hatóanyag felderitése irányába történő orientálását jelenti. "20

Az ítélőtábla szerint kívánalom, hogy nem a tagadó, hanem az eljárást segítő, a szervezeti hierarchiát minél jobban feltáró, a további kábítószer-for-

20 A Fővárosi Ítélőtábla 3.Bf.146/2009/45. számú ítélete. 
galmazást feltáró vallomásaikkal ellehetetlenítő vádlottakat kell előnyben részesíteni.

A titkosszolgálati eszközöket a bíróság álláspontja szerint a le nem leplezett haszonélvezők felderítéséig szükséges igénybe venni, nem kizárólag a függőségük miatt motiválttá tett személyek beazonosításáig. A bíróság egyfajta kritikaként fogalmazta meg, hogy e kívánalom az eljárásban nem járt sikerrel.

A másodfokú bíróság kifejtette, hogy a Fővárosi Bíróság a beismerő vallomást tevő vádlottak esetében súlyosabb büntetést szabott ki, a huszadrendü vádlottat „drákói” büntetésben részesítette, ezért a huszadrendü vádlott föbüntetését hatévi fegyházbüntetésre enyhítette.

A másodfokú ítélet ellen tíz vádlott, illetve mindegyikük védője, valamint az ügyész jelentett be (másod)fellebbezést. A huszadrendű vádlott védője szerint a Fővárosi Ítélőtábla nem vette figyelembe azt, hogy a holland bünszervezet nagy összegü vérdíjat tüzött ki a védencére, illetve hogy a büntetöeljárás alatt a hozzátartozóját, illetve a jogi képviselőjét megfenyegették. A huszadrendủ vádlott a tanúvédelmi szolgálat védelme alatt áll, a védő szerint ebből az következik, hogy az ügyészség vele megállapodott.

A harmadfokú eljárásban a Legfelsőbb Bíróság a Fővárosi Ítélőtábla ítéletét tíz vádlott esetében megváltoztatta: a kiszabott szabadságvesztés-büntetést csak a huszadrendủ vádlott esetében módosította, a fegyházbüntetését kilenc évre súlyosította. A Legfelsőbb Bíróság kiemelte, hogy tévedett az ítélőtábla a büntetés huszadrendủ vádlott vonatkozásában történő kiszabásakor, ugyanis a vádlott a hazánkban múködő, kábítószer-kereskedelemmel foglalkozó egyik legnagyobb bünszervezet létrehozója, szervezője, irányítója volt. A vádlott rendkívüli kiemelkedő tárgyi súlyú büncselekményt követett el, a Legfelsőbb Bíróság álláspontja szerint - a beismerő vallomás ellenére is - a másodfokú bíróság által kiszabott szabadságvesztés kirívóan enyhe, sérti a belső arányosságot.

A Legfelsőbb Bíróság kifejtette, hogy a 4/2005. számú BJE határozat egyértelmü értelmezést ad az alanyi bünösség és a bűnszervezet tárgyi ismérvei közötti viszonyra. E szerint elöször mindig a konkrét büncselekmény elkövetését kell vizsgálni, bizonyítani, ez után - mint tárgyi körülményt - kell elhelyezni egy másik tárgyi körülmény, a bűnszervezet körébe.

A következő lépés annak alanyi oldalon történő vizsgálata, ha az elkövetési magatartás a bünszervezet keretén belüli, akkor e tényt az elkövető felismerte-e. A felismerésnek két fajtája van: lehetséges, hogy az elkövetés a bünszervezeten kívül kezdődik és az elkövetőben csak később tudatosul, hogy 
bünszervezetben van, de benne marad; továbbá a felismerés történhet úgy is, hogy az elkövetés eleve a bünszervezeten belül kezdődik. A bünszervezeten belül kezdődő elkövetés esetén a tettes tudja, hogy milyen keretek között tevékenykedik.

Az előbbiekben vázoltak után a Legfelsőbb Bíróság megállapította, hogy az elsőfokú ítéleti tényállás alapján nem fér kétség a bünszervezet létéhez, illetve a vádlottak kábítószerrel összefüggésbe hozható magatartásához. A tárgyi körülmények alapul szolgálnak a bíróság azon következtetésére, hogy a vádlottak tudata átfogta magatartásuk nem elszigetelt voltát, azazhogy tevékenységük egy kiépített, szervezett elosztó mechanizmushoz kapcsolódik. A bíróság szerint ,, kábítószer esetében pedig az ilyen mechanizmus - értelemszerüen - nem lehet más, mint bünszervezet" ${ }^{21}$.

A vádlottak - a huszadrendủ kivételével - egy már müködő bünszervezethez kapcsolódtak, a bíróság szerint nem annak van jelentősége, hogy ki és mennyi ideig vesz részt a bünszervezetben, hanem annak, hogy a bünszervezet milyen hosszan tevékenykedik.

\section{Ötödik ügy}

Az első- és másodrendű vádlott 1996 óta kábítószer-terjesztést folytatott; a speedport, az ecstasy tablettákat, a marihuánát, a kokaint az elsőrendủ vádlott - akinek külföldön fel nem derített kapcsolatai voltak - Belgiumban, Németországban, illetve Hollandiában szerezte be.

Az elsőrendủ vádlott saját maga, illetve futárok segítségével csempészte Magyarországra a kábítószert. A bünszervezetben a másodrendủ vádlott a terjesztésért, terítésért felelt, dílereket kutatott fel, majd a tevékenységüket összehangolta, illetve a kábítószert rejtekhelyeken tárolta. A másodrendủ vádlott a kábítószer fajtájáról, mennyiségéről, illetve az árakról az elsőrendű vádlottal állapodott meg. A harmadrendủ vádlott nagy tételben vett át értékesítési célból a másodrendủ vádlottól kábítószert, amelyeket rejtekhelyeken tárolt; ő végezte a hígítást, porciózást. A szervezetben a harmadrendủ vádlott feladata volt a kábítószer eljuttatása a viszonteladóknak, az úgynevezett kisebb dílereknek, illetve a fogyasztóknak. Az ötödrendủ vádlott később csatlakozott a bünszervezethez, az ő feladata a tárolóhely, lerakat előteremtése volt. A harmadrendủ vádlott az ötödrendủ vádlott által létrehozott tárolóhelyen mérte,

21 A Legfelsőbb Bíróság Bhar.III.616/2010/24. számú ítélete. 
csomagolta, adagolta a kábítószert; a dílerek több alkalommal ezen a helyen vették át a kábítószereket. A harmadrendủ vádlottat alkalmi ismerősei segítették az említett tevékenységek során, az ilyen esetekben is kizárólag a harmadrendủ vádlott számolt el a másodrendủ vádlottal a kábítószerek árával. A hetedrendủ vádlott a harmadrendủ vádlottól vásárolt kábítószert viszonteladóknak, illetve fogyasztóknak történő értékesítés céljából. A hetedrendủ vádlott tudata átfogta, hogy az általa a harmadrendủ vádlottól vásárolt kábítószer a másodrendủ vádlottól származik. ${ }^{22}$

A bíróság tényként állapította meg, hogy ,az I.r. vádlott, II.r. vádlott, III.r. vádlott és VII.r. vádlott tisztában volt azzal, hogy olyan csoport tagjai amely a kábitószerek Magyarországra történö behozatalának megszervezésében valamint a kábitószerek folyamatos forgalomba hozatalával hosszabb időre tervezett összehangoltan müködö csoportban valósul meg"23.

Az említett személyeknek tudomásuk volt arról, hogy az összehangolt magatartásuk nyomán nagy tételben kábítószer jut el a dílerekhez, illetve a fogyasztókhoz. A vádlottak által kialakított értékesítési láncolat gyakorlatilag korlátlan értékesítési lehetőségeket jelentett.

Az ügyben közremüködtek olyan vádlottak is, akik nem vettek részt a bünszervezet müködésében.

A vádlottak, illetve a védők vitatták a bủnszervezet megállapíthatóságát; arra hivatkoztak, hogy a kereskedéssel elkövetett visszaélést kizárólag kisebb-nagyobb szervezettséggel lehet elkövetni.

Az elsőfokú bíróság vizsgálta a jogszabályváltozások miatt, hogy az első-, másod-, harmad-, ötöd- és hetedrendű vádlottak cselekménye az elkövetéskor hatályos bünszervezet fogalmi elemeinek is megfelelt-e. A bíróság akként foglalt állást, hogy ha az előbbiekre igen a válasz, csupán akkor vizsgálandó az elbíráláskor hatályos bủnszervezet-fogalom.

A bíróság részletes leírást adott a bűnszervezet fogalmának változásáról, illetve a jogintézmény keletkezéséröl. Kitért arra is, hogy az elbíráláskor szintén módosult a bünszervezeti definíció, e szerint a bünszervezet három vagy több személyből álló, hosszabb időre szervezett, összehangoltan müködő csoport, amelynek célja ötévi vagy ezt meghaladó szabadságvesztéssel büntetendő szándékos büncselekmények elkövetése.

\footnotetext{
22 A Fővárosi Bíróság 15.B.196/2003/453. számú itélete; a Fővárosi Ítélőtábla 3.Bf.243/2009/24. számú ítélete.

23 A Fővárosi Bíróság 15.B.196/2003/453. számú ítélete.
} 
A bünszervezet fogalmát jelentő müködésre vonatkozó, elbíráláskor hatályos szabályozás az elsőfokú bíróság szerint egyszerüsödött, az alá-fölé rendeltség helyett az összehangolt müködés a bünszervezet tagjai között az öszszekötő elem. A bíróság szerint „,nem hangsúlyos a személyi kapcsolatok jelentösége sem a bünszervezettel kapcsolatban, az összehangoltan müködö csoport esetében ugyanis a tevékenységen keresztüli kapcsolódás a döntö elem. Ez csupán annyit jelent, hogy a szervezet müködését olyan koordináció jellemzi, amely nem csupán egyetlen cselekményre jellemzö. " ${ }^{24}$

Az elsőfokú bíróság megállapította, hogy a bủnszervezet tagjai tudata átfogta a bünszervezeti minősítéshez szükséges tényeket. A bíróság kiemelte, hogy ,,az elkövetö tudatának nem arra kell kiterjednie, hogy egy bünszervezet a törvényi elöfeltételek szerint létrejött, hanem arra, hogy a bünszervezet tárgyi sajátosságai értelmében, ismeretében ennek müködéséhez csatlakozik illetve ennek keretében cselekszik" ${ }^{25}$. Továbbá nem feltétel a bünszervezet tagjai között a közvetlen kapcsolat, sőt még az egyéb büncselekmények, illetve más elkövetők konkrét ismerete sem.

A vádlottak tevékenysége a kábítószer-terjesztésre létrehozott „vállalkozás" része volt, a résztvevőknek tudomásuk volt arról, hogy a különböző kábítószerek külföldi beszerzésére, hazánk területére való csempészésére, értékesítésére csak magas fokú szervezettség révén van lehetőség, az ilyesfajta szervezettség pedig a bünszervezet jellemzője.

Az elsőfokú bíróság megállapította, hogy az első- és másodrendű vádlottak által vezetett bünözői csoport bünszervezetet alkotott, mivel a szervezet a törvényi kritériumok mindegyikét magán viselte. Kizárólag egy haszonszerzésre törekvő, szervezetben müködő csoport alkalmas annak megszervezésére, hogy külföldröl folyamatosan nagy mennyiségben jusson el kábítószer hazánkba.

Az ítélet ellen az ügyész súlyosításért; a vádlottak, illetve védőik felmentésért, enyhítésért jelentettek be fellebbezést.

Az ítélőtábla nyolc vádlottal szemben változtatta meg az elsőfokú ítéletet, a változtatások a minősítéseket, a büntetések mértékét érintették, az itélet jogerőre emelkedett. Az elsőfokú bíróság az ismertetett tényállás alapján öt vádlott vonatkozásában mondta ki a bünszervezetben történő elkövetést, azonban a Fővárosi Ítélőtábla mellőzte a bűnszervezet megállapítását. 
Az ítélótábla megállapította, hogy a Fővárosi Bíróság ítéleti tényállása döntően megalapozott, azonban kifejtette, hogy annyiban mégsem, hogy tartalmaz olyan, a bünszervezetre vonatkozó megállapításokat, amelyekre nem lehetett a beszerzett bizonyítékokból következtetéseket levonni. A Fővárosi Bíróság a bűnszervezet kritériumaihoz tartozó - egyébként bizonyítékokkal nem alátámasztott - megállapításokat tett, amelyeknek azonban nem volt ténybeli alapjuk. A bizonyítékok értékelésének ismertetésénél a Fővárosi Bíróság nem hivatkozott olyan vallomásra vagy lehallgatási anyagra, amelyből a vádlottak közötti alá-fölé rendeltségre lehetett volna következtetni. Az ítélőtábla álláspontja szerint a vádlottak kapcsolatát az üzleti alapú mellérendeltségi viszony jellemezte.

\section{Hatodik ügy}

A bünszervezet tagjai különféle módszerekkel - így hasüregbe történő „nyeléssel", testre erősítve, illetve preparált táskákban, cipőkben - csempésztek kábítószert repülőgépen. A szervezet tagjainak leleményességét bizonyítja, hogy a kábítószer-csempészet új módszerét is kitalálták: az egyik futár a kábítószerrel átitatott ruhát, a társa pedig a kokain kinyerésére szolgáló oldószert juttatta volna a célországba. E módszerről a hatóságok az egyik lehallgatott telefonbeszélgetésböl szereztek tudomást: „Kémiai összetevökböl készitenek anyagot, abból kiszabnak egy ruhát, amit valaki felvesz vagy beteszi egy böröndbe. S jön vele egy másik ember is, aki hozza a folyadékot, amivel össze kell önteni a ruhát." ${ }^{26}$ Az utanként három-négy ezer eurót kereső drogfutárok által egy alkalommal történő csempészett kokain mennyisége jellemzően fél és két kilogramm között mozgott. Az elsőrendű vádlott megbízásából a harmad- és tizenkettedrendű vádlottak szervezték be a drogfutárokat. A bíróság szerint a bünszervezetben az első-, a másod- és a tizenkettedrendü vádlottak irányítói, a harmad-, ötödrendű vádlottak szervezői, a negyed-, hatod-, hetedrendű vádlottak közremüködői szerepet töltöttek be. A futárok utazásainak költségeit, illetve a költőpénzt az első- és a másodrendű vádlottak állták, továbbá ők szabták meg a csempészésért járó ellenszolgáltatás mértékét. A pénzek címzetteknek történő eljuttatására a bünszervezet a Western Union átutalási rendszerét használta. A tizenkettedrendű vádlott „karrierjét” szemlélteti, hogy kezdetben tízszer-hússzor ő is drogot csempészett, ez után

26 A Borsod-Abaúj-Zemplén Megyei Bíróság 12.B.302/2007/244. számú itélete. 
vált szervezővé. A bünszervezet által csempészett kokain mennyisége meghaladta a jelentős mennyiség alsó határának kétszázharmincnyolcszorosát. ${ }^{27}$

A telefonlehallgatások bizonyították, hogy az elsőrendủ vádlott instrukciókkal, utasításokkal látta el a tizenkettedrendü vádlottat az egyik drogfutár útjával kapcsolatban: „Ne egyen a repülőn, csak igyon, de ne gyümölcslevet, csak ásványvizet és nagyon fontos, hogy az ételét turkálja össze! [...] legyen nála valami rágcsálnivaló vagy szendvics, nehogy feltünjön, hogy nem evett semmit! Ne hivjon fel senkit az ismerösei közül!"”

Az ügy kuriózuma, hogy a bünszervezet egyik drogfutára hetvenegy éves volt, a nagymama az unokájával együtt csempészett kábítószert. A futárok többsége anyagi nehézségek miatt vagy kalandvágyból vágott neki a csempészutaknak; olyanra is akadt példa, hogy kiszolgáltatott helyzetben lévő megtévesztett vagy átlagos felismerési képességgel nem bíró - személyeket vettek rá a futárkodásra.

A futárokat betanították, hogy mikor hova kell menniük, hol kell megszállniuk, kivel kell tartaniuk a kapcsolatot. Velük próbanyeléseket hajtattak végre, a preparált cipők miatt levették a lábméretüket. A csempészés sikertelensége esetén - ha a futár lebukott - a szervezet tagjai magára hagyták a futárt, azonnal megszakították vele a kapcsolatot.

A bíróság kiemelte, hogy a szervezet minimális létszámának meghatározása, szervezettsége, összehangolt müködése lényegileg ténykérdés; a müködés hosszabb időtartamára és a csoport céljára a tényállás értékelésével lehet következtetéseket levonni. A bünszervezet fogalmának a bíróság szerint nem része a jogtalan vagyoni haszonszerzés célzata, sem akár egyetlen büncselekmény befejezése vagy megkísérlése sem.

A bünszervezetben történő elkövetés megállapításához elengedhetetlen az elkövetők ez irányú tudattartalmának vizsgálata. A bíróság kitért rá, hogy a vizsgálat első lépcsője az alapcselekmény tényállásszerüségéhez szükséges bizonyítékok vizsgálata. Párhuzamosan vizsgálni kell a bizonyítási eszközökből származó, és a bűnszervezet törvényi kritériumaira következtetést megalapozó bizonyítékokat.

Az elsőfokú bíróság kifejtette, ,, amennyiben bizonyitott, hogy a büncselekményt egy tényleges bünszervezet müködéséhez kapcsolódva, illetve annak keretei között követték el, úgy a végrehajtás körülményeiböl, különösen a konkrét

27 Uo.; a Debreceni Ítélőtábla Bf.III.638/2009/43. számú ítélete.

28 A Borsod-Abaúj-Zemplén Megyei Bíróság 12.B.302/2007/244. számú ítélete. 
magatartás mások megelözö vagy további láncolatos cselekményeit feltételezö jellegéböl, ezek szükségszerü és ezért elöreláthatóan bekövetkezö eseményeiböl lehet következtetést vonni arra, hogy az alkalomszerü tettes (részes) cselekménye megvalósitásakor a bünszervezetbeni elkövetést felismerte "29.

A tényállásból kitünően a terheltek - más, fel nem derített magyar és külföldi állampolgárokkal együtt - éveken át müködő csoportot alkottak, amely megfelel a törvényi feltételeknek mind a szervezettség, mind a müködés öszszehangoltsága tekintetében. A szervezettséget, illetve az összehangoltságot a munkamegosztás is bizonyította, a kábítószer ellenértékének átadását a szervezők nem bízták a kizárólag szállítást végző futárokra. A bünszervezet a konspiráció szabályai szerint müködött, erre kiváló példa a fedőnevek használata, azok váltogatása, illetve a dezinformálás. A bünszervezet tagjai a lebukást elkerülendő vesztegetéseket is alkalmaztak.

A szervezettségre jellemző, hogy a vezetők, illetve megbízottaik szervezték meg a futárok utaztatását, gondoskodtak a szállásról, ellátásról. A drogfutárok szoros felügyeletét bizonyítja, hogy meggyőződtek a kokain „nyeléséről”, illetve figyelték a futár felszállását a repülőgépre. A célállomáson a megbízott személyek várták a drogfutárokat; a „nyeléses”, illetve a preparált eszközökben történő becsempészett kábítószer esetén megoldották a biztonságos helyre szállítást, ahol a kábítószer átvétele nem ütközött akadályba.

A bíróság megállapította, hogy ,, a kontinenseket átfogó, az utazás minden részletét megtervezö, összehangolt kábitószer-csempészet lebonyolitására csak bünszervezet képes" ${ }^{30}$.

A tizenkét vádlott ellen folytatott eljárásban nyolc vádlottal szemben állapította meg a bíróság a bünszervezetben történő elkövetést.

Az ügyész tizenegy vádlott terhére jelentett be fellebbezést; a vádlottak és védőik enyhítésért, felmentésért, illetve a minősítés megváltoztatása érdekében fellebbeztek.

A Debreceni Ítélőtábla mint másodfokú bíróság három vádlott tekintetében hatályon kívül helyezte az ítéletet, és az elsőfokú bíróságot új eljárásra utasította. Egy vádlott vonatkozásában mellőzte a bünszervezetben elkövetés megállapítását, kilenc vádlottnál az elsőfokú bíróság ítélete jogerőre emelkedett.

A hatályon kívül helyezés nem befolyásolta az elsőfokú bíróság megállapításait - ezek alapja a többi vádlott vallomása, a lehallgatási anyag volt -, 
amelyek az érintett vádlottak bünszervezetben betöltött funkcióira, szerepeire vonatkoztak.

Az ítélőtábla egy vádlott kivételével egyetértett az elsőfokú bíróság bünszervezet megállapításával kapcsolatos érvelésével.

A Debreceni Ítélőtábla fontosnak tartotta megjegyezni, hogy „önmagában az egyszeri elkövetés, $s$ ebböl adódóan az eseti jelleg nem feltétlenül zárja ki a bünszervezet megállapitását "' ${ }_{31}$. Azonban a másodfokú bíróság a megyei bíróság indokaival egyetértve kifejtette, hogy nem vonható következtetés arra, hogy bizonyos vádlottak tisztában voltak azzal, hogy a tevékenységük egy bünszervezethez köthető.

\section{Hetedik ügy}

Az elsőrendủ vádlott által irányított, 2006 ősze és 2007 áprilisa között müködő csoport célja kábítószer-beszerzés és -terjesztés volt. A vádlott finanszírozta a kábítószert, illetve gondoskodott az utánpótlásról, azonban néhány kivételtől eltekintve nem került közvetlen kapcsolatba a kokainnal. Az elsőrendű vádlott utasításai szerint a negyedrendủ vádlott tárolta, hígította, mérte ki, csomagolta a kábítószert. A negyedrendủ vádlott értékesítette a fogyasztók, illetve a viszonteladó részére a kokaint, a bevétellel az elsőrendủ vádlottal számolt el. A csoportban a harmad-, ötöd-, tizennegyed- és tizenhatodrendủ vádlottak viszonteladói szerepet töltöttek be, a megrendeléseiket a negyedrendú vádlottnak adták le. A negyedrendủ vádlott napi szinten tájékoztatta a megrendelésekről, találkozásokról, értékesített kokain mennyiségéröl, minőségi kifogásokról, a megrendelők tartozásairól az elsőrendủ vádlottat. A negyedrendü vádlott nem dönthetett önállóan, minden esetben az elsőrendủ vádlott utasításainak megfelelően járt el. A csoport terjesztỏi tevékenysége három városra, illetve azok környékére terjedt ki. A csoport tagjainak elfogásakor a rejtekhelyen a rendőrség több mint négy kilogramm kokaint foglalt le. ${ }^{32}$

A tizenöt vádlott elleni büntetőügyben a vád kereskedéssel, bünszervezetben elkövetett kábítószerrel visszaélés büntette volt, azonban a bíróság nem állapította meg a bünszervezetben történő elkövetést.

\footnotetext{
31 A Debreceni Ítélőtábla Bf.III.638/2009/43. számú ítélete.

32 A Vas Megyei Bíróság 8.B.80/2010/13. számú ítélete; a Győri Ítélötábla Bf.119/2010/20. számú ítélete.
} 
A bíróság szerint a csoport működését a konspiráció jellemezte, a vádlottak váltogatták a telefonszámaikat, ezekről tájékoztatták egymást, illetve a dílereket, fogyasztókat. A telefonbeszélgetések során a közlések tartalmát igyekeztek minimalizálni, arra törekedtek, hogy a kívülállók ne értsék meg. Virágnyelven beszéltek a kokainról, soha nem nevezték meg a kábítószert, sőt a mennyiségre, árra vonatkozóan is kódolt nyelvet használtak. A centiméter, kilogramm, palacsinta, pótkerék, euró, csempe, papír, fagyálló, lakás, dosszié és másolat kifejezések alkalmazása rendszeres volt a beszélgetések során; több alkalommal úgy fogalmazták meg a rendelt kokainmennyiséget, hogy hány percre kell találkozniuk.

A konspirációra utal, hogy a kábítószer rejtekhelyéül szolgáló lakásban ki kellett kapcsolni a telefonokat. A lehallgatott beszélgetések alapján megállapítható, hogy az elsőrendủ vádlott ezen utasítását a negyedrendü vádlott több esetben megszegte.

A bíróság kifejtette, , ha a különleges eszközök alkalmazásának oka a büncselekmények sorozatban vagy szervezett elkövetéssel történö megvalósulása, akkor a nyomozó hatóság nyilván nem lép közbe az elsö vagy második megfigyelt, lehallgatott büncselekmény után, mert akkor a célt, azaz az elkövetök lehetö legnagyobb körének felderitését és bünösségüknek bizonyitását a sorozatban vagy szervezetten elkövetett büncselekményekben, nem érheti el'"33.

A bíróság szerint a bizonyítás során felszínre kerültek a nyomozási hiányosságok is, amelyek a bizonyítékok értékelése, a minősítés - így különösen a bünszervezet megállapíthatóságát illetően - tekintetében problémát okoztak.

A bíróság a telefonlehallgatási anyagot nem a nyomozó hatóság által rendszerezett formában tette a bizonyítás részévé, mivel a bizonyítás felvételénél nyilvánvalóvá vált az eredménytelenség, azaz nem lehetett megállapítani a terjesztői hálózat müködését, a vádlottak elkövetési magatartását. A bíróság az említettek miatt kronológiailag rendszerezte az összes lehallgatási anyagot, és ezt tette a bizonyítás részévé.

Az ítélet kitért arra, hogy a nyílt nyomozás a Vas Megyei Rendőr-fökapitányság felderítő osztályának feljelentése alapján indult. A feljelentés huszonkilenc személyre vonatkozott, azonban a bíróság megállapította, hogy a feljelentés mellékletében részletezett jelentésben a hatóság harmincnégy személlyel szemben fogalmazta meg az alapos gyanút.

A bíróság szerint a büntetőfeljelentésben szereplő személyek közül kilenccel szemben ténylegesen büntetőeljárás sem folyt. Több személy eseté-

33 A Vas Megyei Bíróság 8.B.80/2010/13. számú ítélete. 
ben konkrét adatok vetődtek fel súlyos büncselekmény elkövetésére, de nem került sor ezek vonatkozásában nyomozati cselekményekre. A bíróság kifejtette, hogy a nyomozati iratok adataiból kitünően a nyomozó hatóság jóval több elkövető ellen folytathatott volna büntetőeljárást.

A nyomozás további hiányossága, hogy a nyomozó hatóság nem szerezte be a híváslistákat, amelyek a vádlottak kapcsolatrendszerét bizonyíthatták volna, különös tekintettel a hozzájuk köthető személyekre. Továbbá kiemelendő, hogy a nyomozó hatóság elmulasztotta kiértékelni a lefoglalt telefonokban rögzített adatok tartalmát, emiatt további elkövetők, illetve fogyasztók kiléte ismeretlen maradt. A híváslisták alapján a cellapozíciók beazonosítása is lehetővé vált volna, ezek a találkozók tényleges megtörténtét bizonyíthatták volna. Az előbbiekben ismertetett hiányosságok a bírósági eljárásban nem voltak pótolhatók.

Az elsőfokú bíróság rámutatott, hogy a legvitatottabb kérdések között szerepelt a bünszervezet megállapíthatósága a vádlotti, illetve a védői kör felöl. Az érvelések során arra hivatkoztak, hogy a nyomozás idején nem folytattak bünszervezettel kapcsolatos bizonyítási eljárást; a gyanúsításokban nem szerepelt, hogy vezetőként vagy tagként követték el a büncselekményeket; továbbá a vádirat sem tartalmaz ilyen megállapításokat.

A bíróság kiemelte, hogy a törvény rendkívül szigorú következményeket füz a bünszervezetben történő elkövetéshez, ezért szigorúan kell értelmezni és bizonyítékokkal alátámasztani a bünszervezet kritériumainak meglétét is. Az ítélet szerint a bünszervezetre vonatkozóan ,, a nyomozó hatóság külön bizonyitást nem folytatott le, még csak olyan szinten sem, hogy azon vádlottak esetében, akik hajlandók voltak tényfeltáró vallomást tenni, részletes és mindenre kiterjedö kihallgatást folytasson le" ${ }^{34}$.

A nyomozási hiányosságokon kívül egyéb eljárási anomáliákkal is szembesültek az eljárás során, ugyanis számos elkövető esetében elkülönítették a nyomozást.

A bíróság végül azt a következtetést vonta le, hogy „...itéleti bizonyossággal nem állapitható meg és alapos következtetés sem vonható arra nézve, hogy az érintett vádlottak büncselekményeiket a Btk. 137. § 8) pontjában irt bünszervezetben követték volna el ${ }^{{ }_{3} 5}$. 
A bíróság azonban leszögezte, hogy az elsőrendủ vádlott által irányított hálózatban minden vádlottnak meghatározott feladata volt, és az egyéb bizonyítékok is rendelkezésre álltak a bünszövetség megállapítására.

A Vas Megyei Bíróság az ítéletében tizenhárom vádlott büntetőjogi felelősségéről határozott, tíz vádlott vonatkozásában az ítélet első fokon jogerőre emelkedett. Az ítélet ellen az első-, negyed-, illetve tizennegyedrendü vádlott, illetve a védőik fellebbeztek. A fellebbviteli föügyészség nem fellebbezett az ítélet ellen, azonban az átiratában kiemelte azokat a tényállási elemeket, amely megalapozhatták volna a bünszervezetben történő elkövetést.

A vádlottak és a védők az ügyészség indítványa kapcsán arra hivatkoztak, hogy súlyosítási tilalomba ütközik, továbbá megalapozatlan a bünszervezet megállapítására vonatkozó ügyészi okfejtés.

Az ügyészség képviselője a másodfokú nyilvános ülésen visszavonta a bünszervezetben elkövetés megállapítására tett indítványt. Az ítélőtábla azonban szükségesnek tartotta rögzíteni, hogy a bünszervezet megállapítása nemcsak jog-, hanem ténykérdés is, ,, létének leigazolása külön erre vonatkozó komoly bizonyitás lefolytatását igényli, amely ahogy az elsőfokú biróság is hivatkozott rá, jelen ügyben a felderités körében elmaradt, késöbb pedig már nem volt pótolható" ${ }^{\prime 36}$.

A másodfokú bíróság megjegyezte, hogy a bünszervezet másodfokú eljárásban történő megállapítása a hatályos rendelkezések szerint a vádlottak terhére bejelentett ügyészi fellebbezés hiányában sem ütközik a súlyosítási tilalomba.

Az ítélőtábla az elsőfokú itéletet három vádlott vonatkozásában egyebekben helybenhagyta.

36 A Győri Ítélőtábla Bf.119/2010/20. számú ítélete. 